\title{
The Democracy Problem
}

\author{
Leonard Williams*
}

Anarchist thought often adopts an anti-political stance. Generally opposed to any form of rule or domination, anarchists have recently embarked on sustained critiques of common understandings of democracy. Despite such critiques, experiences with participatory decision-making in spokescouncils and occupations suggest that anarchism retains some democratic commitments. Indeed, any number of anarchist thinkers have highlighted those commitments from time to time - for example, Murray Bookchin's libertarian municipalism (with its apparent "polis envy") or David Graeber's more recent claim that anarchism is "democracy without the government." As anarchists elaborate a utopian vision and sketch the outlines of a new society, it is vital to develop an anarchistic conception of democracy. This essay identifies criteria to be met by a democratic anarchism and highlights the models of democracy that might guide anarchist thinking. On such a basis, anarchists can outline a compatible understanding of democracy, one that lies somewhere between antagonism and consensus. [Article copies available for a fee from The Transformative Studies Institute. E-mail address:_journal@transformativestudies.org_Website: http://www.transformativestudies.org (C2020 by The Transformative Studies Institute. All rights reserved.]

KEYWORDS: Anarchism, Democracy, Community, Decision-Making, Direct Democracy.

\section{THE DEMOCRACY PROBLEM}

Anarchism has long been promoted and viewed as an oppositional, revolutionary doctrine. Recent takes have described its approach as, for

\footnotetext{
${ }^{*}$ Leonard Williams, Ph.D., is professor of political science at Manchester University in North Manchester, Indiana. He teaches courses in political theory and American politics, focusing his research on political ideologies. His work on anarchism has appeared in a number of journals and in Anarchism: A Conceptual Approach (which he co-edited with Benjamin Franks and Nathan Jun). Address correspondence to: Leonard Williams; email: lawilliams@manchester.edu.
} 